\title{
PENGARUH PROGRAM BINA DIRI TERHADAP KEMANDIRIAN ANAK TUNAGRAHITA
}

(Studi quasi Eksperimen Mengenai Pengaruh Program Bina Diri di SLB Abc Argasari Yayasan Lestari Tasikmalaya terhadap Kemandirian anak Tunagrahita Kategori Ringan)

\section{Emil Kurniawan}

Fakultas Psikologi UIN Sunan Gunung Djati Bandung, Jl. A.H Nasution No. 105 Bandung

\begin{abstract}
Abstrak
Tujuan dari penelitian ini untuk mengetahui efektifitas dari penerapan program Bina Diri di SLB Abc Argasari Yayasan Lestari Tasikmalaya terhadap kemandirian anak tunagrahita (kategori Ringan). Metode penelitian yang digunakan adalah quasi-eksperimen dengan rancangan single subject research dengan pola multiple baseline design. Instrument pengumpulan data menggunakan alat ukur observasi dengan metode Rating Scale dan pedoman wawancara. Hasil analisis menunjukan adanya peningkatan skor pada fase treatment. Dengan demikian dapat disimpulkan bahwa terdapat pengaruh program bina diri di SLB Abc Argasari Yayasan Lestari Tasikmalaya terhadap kemandirian anak tunagrahita (Kategori Ringan).
\end{abstract}

Kata Kunci : Program Bina Diri, Kemandirian Anak Tunagrahita

\section{Abstrak}

This research aims to know the effectiveness of self-improvement application toward autonomy of mentally disabled children (medium category) at school of special needs students (SLB) Abc Argasari Yayasan Lestari Tasikmalaya. Quasiexperiment using single subject research design and multiple baseline design is used. Collecting data used observation with Rating Scale instrument and interview. Result shows that there is an increasing score in treatment phases. It ca be concluded that self-improvement program effect the autonomy of mentally disabled children at School of special needs students (SLB) Abc Argasari Yayasan Lestari Tasikmalaya.

Keywords: Self-improvement program, autonomy of mentally disabled child

\section{PENDAHULUAN}

Manusia telah diciptakan Alloh SWT sebagai makhluk yang sempurna dalam segala hal dibanding dengan makhluk yang lain. Kesempurnaan manusia dari segi fisik memiliki daya tarik terhadap suatu keindahan dan kekuatan tubuh sedangkan dari segi rohani manusia diberikan akal dan pikiran untuk mengembangkan diri sehingga manusia menjadi yang beradab dimuka bumi ini. Kesempurnaan ini ternyata tidaklah seluruhnya bagi manusia karena masih ada yang diciptakan oleh Tuhan yang memiliki kekurangsempurnaan baik dalam segi fisik maupun dalam segi mental atau yang sering kita sebut dengan anak berkelainan/anak.

Sejak lahir manusia dibekali potensi yang positif, dengan begitu manusia dipandang sama-sama mempunyai potensi- 
potensi tersebut hanya saja kadar dari setiap masing-masing individu dan bagaimana individu tersebut menggunakan potensi tersebut. Hal ini sesuai dengan hadist Nabi SAW : "setiap anak dilahirkan dalam keadaan fitrah".

Diluar semua itu sebenarnya labih tepat lagi jika arti kata "Fitrah" lebih dimaknai sebuah "Potensi". Sehingga makna hadits Nabi "setiap anak dilahirkan dalam keadaan suci" secara lebih luas dimaknai sebagai "Semua Anak Lahir di Dunia lahir dalam keadaan Membawa Potensi". Setelah dimaknai seperti inilah baru kita bisa menentukan perjalanan hidup manusia di masa berikutnya.

Anak berkebutuhan khusus yang telah diartikan sebagai anak yang mengalami kelainan baik secara phisik, intelektual, sosial, dan emosional dalam pertumbuhannya sehingga mereka memerlukan pendidikan khusus. Anakanak yang termasuk dalam golongan anak berkebutuhan khusus saat ini semakin banyak jenisnya antara lain anak tunanetra, tunarungu, tunagrahita, tunadaksa tunalaras, anak berbakat, anak berkesulitan belajar spesifik, anak indigo, anak berpenyakit kronis, autisme, dan anak gangguan komunikasi. Adapun jumlah anak berkebutuhan khusus yang telah tertangani di lembaga pendidikan adalah 81.434 anak.( Dit.PSLB 2006).

Anak tunagrahita sebagai salah satu anak berkebutuhan khusus memiliki berbagai kekurangan. Kekurangan tersebut salah satunya dalam kemampuan merawat dirinya sendiri. Hal ini terjadi karena rendahnya kecerdasan yang dimiliki. Dengan keterbatasan kecerdasan ini anak tunagrahita tidak dapat melakukan tindakan yang dapat menolong dirinyasendiri.

Sebagaimana kita ketahui bersama, tingkah laku anak tunagrahita bila berada di dalam lingkungan masyarakat normal, akan berlainan dengan anak-anak pada umumnya. Pada anak cacat mental terdapat beberapa sifat khusus yang harus diperhatikan agar tidak timbul interprestasi yang salah terhadap mereka yang normal bila mereka bersikap lain dari masyarakat sekelilingnya.

Anak pada umumnya akan dapat melakukan cara memegang sendok dan memasukannya ke mulut untuk makan sesuai dengan umurnya. Mereka tidak perlu ada bantuan untuk melakukan sesuatu yang berhubungan dengan perawatan diri. Namun bagi anak tunagrahita dalam perkembangannya akan mengalami keterlambatan dalam melakukan tugas-tugas kehidupan, bahkan sampai dewasapun.

Tidak hanya itu anak yang mengalami ketunagrahitaan juga dari segi kapasitas belajarnya sangat terbatas terutama untuk hal-hal yang abstrak. Mereka lebih banyak belajar dengan cara membeo (rote learning) bukan dengan pengertian. Dalam pergaulan mereka tidak dapat mengurus, memelihara dan memimpin diri. Mereka bermain dengan teman-teman yang lebih muda, tidak dapat bersaing dengan teman sebaya. Tunagrahita sendiri dibagi menjadi tunagrahita ringan, sedang, dan berat.

Dengan kenyataan yang dialami oleh anak tunagrahita dengan ketidaksempurnaanya, maka selaku sesama umat manusia timbul adanya suatu kesadaran untuk berusaha membantu dan menangani anak tunagrahita tersebut, karena sudah sepatutnya kita harus menolong antara satu sama lain.

Pola pelayanan dan penanganan yang diberikan pada anak-anak berkebutuhan khusus semakin lama semakin berkembang seiring dengan perkembangan tehnologi dan kemajuan berpikir sumber daya manusia. Pola penanganan yang masih bersifat tradisional mulai menuju pada pola penanganan yang bersifat modern sehingga untuk pelayanan anak semakin baik. Dari pola penanganan yang berbasis pada anak minded sekarang sudah menuju pada pola penanganan yang berbasis community, sehingga peran masyarakat akan semakin 
besar dalam ikut berpartispasi dalam peningkatan pelayanan anak berkebutuhan khusus.

Seiring dengan lahirnya Undangundang Nomor 20 tahun 2003, tentang sistem Pendidikan Nasional RI dan Peraturan Pemerintah RI No 19 tahun 2005, telah memberikan dampak langsung pada perubahan kurikulum pendidikan yang ditetapkan dengan Permendiknas nomor 22 tahun 2006 tentang standar isi satuan Pendidikan dasar dan menengah, Permendiknas Nomor 2006 tentang standar kompetensi Lulusan untuk satuan pendidikan dasar dan menengah dan Permendiknas nomor 24 tentang pelaksanaan Peraturan Menteri Pendidikan Nasional RI nomor 22 dan 23 tahu 2006.

Berdasarkan Permendiknas di atas telah memberikan perubahan yang signifikan bagi program khusus untuk pendidikan tunagrahita ringan dan sedang, dimana menurut kurikulum 1994 dan KBK sebagai mata pelajaran Kemampuan Diri (KMD), sedangkan saat ini diperluas menjadi mata pelajaran Bina Diri. Secara konsep Bina Diri memberikan makna lebih luas dari kemampuan Merawat Diri (KMD), karena secara langsung KMD menjadi bagian dari pembelajaran Bina Diri.

Program Bina Diri memiliki peran sentral dalam mengantarkan peserta didik dalam melakukan bina diri untuk dirinya sendiri, seperti merawat dan mengurus diri, menjaga keselamatan diri, komunikasi serta adaptasi lingkungan sesuai dengan kemampuannya. Pembelajaran bina diri diarahkan untuk mengaktualisasikan dan mengembangkan kemampuan peserta didik dalam melakukan bina diri untuk kebutuhan dirinya sendiri sehingga tidak sepenuhnya membebani orang lain.

Ruang lingkup program Bina Diri tidak dapat terlepas dari program pembelajaran yang lainnya pada satu satuan pendidikan, dalam pengertian pembelajaran Bina diri dapat saling berkontribusi dengan pembelajaran yang lain, misalnya kebutuhan komunikasi sangat erat kaitannya dengan program pembelajaran bahasa.

Dalam Program Bina Diri ini terdapat berbagai aspek yang harus dikuasi dan dimiliki anak tunagrahita, sehingga setiap anak dapat hidup wajar sesuai dengan fungsi-fungsi kemandirian, antara lain : merawat diri, mengurus diri, menolong diri, komunikasi, sosialisasi/adaptasi, keterampilan hidup, mengisi waktu luang.

Adapun materi bina diri yang diberikan meliputi 1) usaha membersihkan dan merapikan diri, 2) berbusana, 3) minum dan makan, 4) menghindari bahaya. Ruang lingkup program bina diri menurut Inderajati Sidi (2002: 1) mencakup komponen dan kemampuan sebagai berikut :

1. Merawat diri : makan, minum dan kebersihan

2. Mengurus diri : berpakaian dan berhias

3. Menolong diri : menjaga keselamatan dan mengatasi bahaya.

4. Berkomunikasi : berkomunikasi lisan, tulisan, isyarat dan gambar.

5. Adaptasi seperti : adaptasi dengan lingkungan keluarga. Sekolah, masyarakat, dan bermain/bekerja sama.

Meskipun secara konsep Program Binadiri ini bisa di kategorikan sebagai program yang sangat menjanjikan dan berdasarkan hasil wawancara awal yang peneliti lakukan pada pihak pengajar dimana peneliti melakukan penelitiannya, mereka mengakui bahwa memang program Bina diri ini bisa di lihat hasilnya dengan meningkatnya kemandirian anak.

Namun pada kenyataannya, fenomena yang terjadi dalam penerapan program Bina diri tersebut, sering kali seorang guru kesulitan dalam membantu anak tunagrahita dalam melakukan satu aktifitas bahkan lebih. Ketika anak sudah di ajarkan dalam satu aktifitas misalkan aktifitas dalam berpakaian, ketika sudah diajarkan dan di bantu dalam berpakaian 
sering kali keesokan harinya atau pertemuan berikutnya si anak tidak dapat mengulang apa yang diajarkan oleh gurunya.

Tidak hanya itu saja ketika anak di suruh sesuatu oleh gurunya anak kesulitan untuk melakukannnya, misalkan ketika anak di suruh untuk membuang sampah pada tempatnya, anak tersebut suka lupa kemana sampah tersebut harus di buang. Hal ini menunjukan bahwa dalam menjalankan program Bina Diri ini tidaklah mudah dengan melihat factor pendidik dan factor anak dengan kata lain kedua-duanya.

Tidak mudahnya dalam menjalankan program Bina Diri ini, juga di ketahui peneliti berdasarkan hasil wawancara peneliti dengan salah satu guru di Sekolah Luar Biasa abc argasari yayasan lestari tersebut menyatakan bahwa memang dalam penerapan program tersebut seringkali merasa jengkel karena susahnya anak dalam menyerap apa yang mereka ajarkan, tetapi hal tersebut bukanlah sebuah alasan untuk menghentikan mereka dalam mendidik anak tersebut, justru karena hal tersebut menjadikan motivasi lebih bagi mereka untuk terus mengasah keterampilan dan kesabaran dalam menghadapi anak.

Dengan kondisi yang demikan tentunya pemahaman yang jelas tentang siapa Anak Tunagrahita merupakan dasar yang penting untuk dapat menyelenggarakan layanan pendidikan dan pengajaran yang tepat bagi mereka. Anak Tunagrahita terdapat di kota dan di desa dilakangan atas dan di kalangan rakyat jelata, dalam keluarga kurang terpelajar dan keluarga kurang terdidik, baik dalam keluarga kaya maupun miskin.

Definisi dari American Association on Mental Deficiency (AAMD) adalah bahwa Tunagrahita mengacu pada fungsi intelektual umum yang nyata berada di bawah rata-rata bersamaan dengan kekurangan dalam adaptasi tingkah laku dan berlangsung dalam masa perkembangan. Dalam penelitian ini yang dijadikan subjek adalah anak tunagrahita yang termasuk dalam kategori ringan.

Dengan pemaparan di atas, sebagaimana diketahui bahwa anak mempunyai potensi untuk didik, walaupun kenyataannya anak tunagrahita dalam bertingkah laku berbeda dengan kebiasaan anak normal lainnya, tetapi masih bisa memaksimalkan potensi tersebut dan sebagai tindak lanjut adanya program Bina Diri yang menjanjikan dan sudah ada yang bisa merasakan dan membuktikan mampaatnya sesuai yang di katakan oleh pendidik yang peneliti wawancarai. Namun kenyataannya untuk menjalankan program Bina diri tersebut tenaga pendidik merasa mengalami kesulitan dan terkadang suka merasa jengkel dalam menghadapi anak tunagrahita. maka peneliti tertarik untuk mengetahui lebih lanjut mengenai efektifitas dari program Bina diri yang di jalankan di Sekolah Luar Biasa abc argasari yayasan lestari dalam meningkatkan kemandirian anak tunagrahita.

Berdasarkan latar belakang diatas maka identifikasi masalah pada penelitian ini yakni : " Apakah Program Binadiri Dapat Berpengaruh Tehadap Kemandiriani Anak Tunagrahita (kategori ringan) di SLB Abc Argasari Yayasan Lestari"?

Maksud dari penelitian ini yaitu guna memperolah data yang akurat mengenai variabel-variabel yang terkait dengan penelitian ini dengan tujuan untuk mengetahui efektifitas dari penerapan program Bina Diri terhadap kemandirian anak tunagrahita (kategori sedang ) Sekolah Luar Biasa abc argasari yayasan lestari.Kegunaan teoritis yang ingin peneliti peroleh diharapkan :Untuk menambah wawasan dalam bidang kajian Psikologi Klinis yang berkaitan dengan masalah kemandirian Anak Tunagrahita.Kegunaan praktis yang ingin penelilti peroleh diharapkan : Dapat dijadikan alternatif bagi para Anak 
Tunagrahita dalam meningkatkan kemandirian melalui Program Bina Diri.Sebagai sumbangan karya ilmiah bagi perkembangan ilmu pengetahuan pada umumnya dan lembaga pendidikan luar biasa pada khususnya. Untuk menambah wawasan ilmu bagi guru dalam menangani permasalahan yang berkaitan dengan kemandirian anak tunagrahita

Rancangan quasi eksperimen yang digunakan dalam penelitian ini adalah Single Subjek Research (SSR) atau Single Case (Frederick J. Graveter, dkk, 2006 : 351), menyatakan bahwa single subjek research atau single case design adalah desain penelitian yang menggunakan data dari partisipan atau subjek tunggal untuk membuktikan adanya hubungan sebab akibat dari suatu fenomena, akan tetapi bias juga digunakan untuk penelitian dengan subjek lebih dari satu. Meskipun subjek lebih dari, analisis data untuk masing-masing subjek dilakukan terpisah.

Pendekatan dalam penelitian ini adalah pendekatan kuantitatif dengan metode quasi eksperimen. Desain penelitian quasi eksperimen yang dipakai dalam penelitian ini adalah desain subjek tunggal (single subject research). Pada desain subjek tunggal pengukuran variable terikat atau target behavior dilakukan berulang-ulang dengan periode waktu tertertu misalnya perminggu, perhari atau perjam. Perbandingan ini tidak dilakukan antar individu maupun kelompok tetapi dibandingkan dengan subjek yang sama dalam kondisi yang berbeda.yang dimaksud kondisi di sini adalah kondisi baseline dan kondisi eksperimen (intervensi). Baseline adalah kondisi dimana kondisi target behavior dilakukan pada kondisi natural sebelum diberikan intervensi apapun. Kondisi eksperimen adalah kondisi dimana intervensi telah diberikan dan target behavior diukur di bawah kondisi tersebut. Pada penelitian dengan desain subjek tunggal selalu dilakukan perbandingan antara fase baseline dengan sekurang-kurangnya satu fase intervensi. (sunanto et.al;2005: 56).

Desain single subjek research menggabungkan unsur-unsur studi kasus dan time series. Penggunaan subjek tunggal dan memberikan gambaran observasi yang rinci merupakan unsure studi kasus, sedangkan serangkain pengukuran yang dilakukan secara stimultan dalam periode waktu tertentu merupakan unsure time series design. Rancangan ini terdiri dari fase baseline dan fase treatment. Fase baseline adalah serangkaian pengukuran yang dilakukan sebelum treatment diberikan, sedangkan fase treatment adalah serangkain pengukuran yang dilakukan selama treatment diberikan.

Pola rancangan yang digunakan adalah multiple baseline design, yaitu rancangan single subject research yang menunjukan kondisi treatment dilaksanakan secara berturut-turut pada satu perilaku yang sama dari dua/lebih subjek, dua/lebih perilaku yang berbeda dari satu subjek yang sama atau satu perilaku yang sama dalam situasi yang berbeda(Frederick Graveter \& Lori Ann B Forzano,2006:371). Pada penelitian ini, multiple baseline design digunakan pada dua/lebih perilaku yang berbeda dari satu subjek yang sama. Pola ini dimulai dengan dua fase baseline yang simultan. Fase treatment diberikan pada perilaku 1 dan fase baseline berlanjut pada perilaku 2 . Beberapa waktu kemudian treatment diberikan pada perilaku 2.

Secara operasional yang dimaksud dengan kemandirian dalam peneliitian ini adalah suatu sikap yang di tunjukan oleh anak tunagrahita dimana sikap tersebut menunjukan anak mampu :

1. Merawat diri : kebersihan badan

2. Mengurus diri : makan dan minum, makan/minum bersama, membuat minum, berpakaian dan berhias diri.

3. Menolong diri : memelihara alat rumah tangga.

4. Berkomunikasi 
5. Sosialisasi dan Adaptasi

6. keterampilan hidup

Oleh sendiri tanpa bantuan oleh orang lain.

Variable tidak terkontrol adalah variable yang munculnya tidak dapat diduga dan mempengaruhi jalannya penelitian dan variable tersebut tidak dapat dikontrol oleh peneliti. Variable tidak terkontrol ini sekaligus menjadi hipotesis tandingan ( rival hypothesis ).

Subjek dalam penelitian ini adalah seorang siswa kelas 2 SLB abc Argasari Yayasan Lestari berjenis kelamin laki-laki. Penelitian dilakukan di SLB abc Argasari Yayasan Lestari Cieunteung Tasikmalaya.

\section{Hasil Pengukuran Kemandirian Pada Fase Baseline Dan Treatment}

Hasil ini akan dilihat berdasarkan skor kemandirian pada subjek yang berasal dari pengukuran yang dilakukan tiga kali pada fase baseline dan empat kali pada fase treatment, hasil ini akan dilihat berdasarkan grafik skor kemandirian pada subjek. Berikut adalah identitas subjek.

\section{Subjek}

Nama : R.I.S

Tempat dan tanggal lahir:

Tasikmalaya, 20 Februari 2003

Jenis kelamin

Kelas

$$
\begin{aligned}
& \text { : Laki-laki } \\
& \text { 1 C }
\end{aligned}
$$

Berdasarkan hasil skor yang diperoleh, dapat disimpulkan bahwa skor kemandirian pada subjek terjadi perubahan yakni dari skor yang tadinya rendah sebelum diberikan program binadiri berubah menjadi tinggi setelah diberikan program binadiri atau terjadi peningkatan yang signifikan dari fase baseline (fase sebelum diberikan program binadiri) ke fase treatment (setelah diberikan program binadiri), hal ini berarti bahwa program binadiri berpengaruh terhadap kemandirian anak tunagrahita di Slb Abc Argasari Yayasan Lestari Tasikmalaya.

\section{Hasil Pengukuran Aspek Kemandirian Pada Subjek}

Grafik skor dibuat berdasarkan skor kemandirian setiap sub Aspek dari kemandirian subjek yang terdiri dari skor sebelum diberikan treatment sebanyak 3 kali pengukuran dan skor selama treatmen sebanyak 4 kali pengukuran.

Hasil terlihat ada peningkatan skor yang signifikan antara fase baseline dan fase treatment. Pada fase baseline kemampuan subjek berada pada skor 11, skor ini menunjukan kemandirian subjek masuk dalam kriteria rendah sedangkan pada fase treatment skor meningkat secara bertahap. Pada fase treatment ke-1,ke-2 dan ke-3 skor kemandirian subjek meningkat dari rendah ke sedang dan pada fase treatment ke-4, skor kemandirian subjek meningkat tinggi.

Skor yang signifikan antara fase baseline dan fase treatment. Pada fase baseline kemampuan subjek berada pada skor 21, skor ini menunjukan kemandirian subjek masuk dalam kriteria rendah sedangkan pada fase treatment skor meningkat secara bertahap. Pada fase treatment ke-1, ke-2 da ke-3 skor kemandirian subjek secara bertahap meningkat dari rendah ke sedang dan pada fase treatmentn ke-4, skor kemandirian subjek meningkat tinggi.

\section{Perolehan Skor Aspek Menolong Diri}

Terlihat ada peningkatan skor yang signifikan antara fase baseline dan fase treatment. Pada fase baseline kemampuan subjek berada pada skor 16, skor ini menunjukan kemandirian subjek masuk dalam kriteria rendah sedangkan pada fase treatment skor meningkat secara bertahap. Pada fase treatment ke-1 dan ke-2 skor kemandirian subjek masih berada pada skor sedang dan pada fase treatment ke-3 dan ke-4, skor kemandirian subjek meningkat tinggi. 
Terlihat ada peningkatan skor yang signifikan antara fase baseline dan fase treatment. Pada fase baseline kemampuan subjek berada pada skor 10, skor ini menunjukan kemandirian subjek masuk dalam kriteria rendah sedangkan pada fase treatment skor meningkat secara bertahap. Pada fase treatment ke-1 dan ke-2 skor kemandirian subjek masih masuk dalam kriteria sedang dan pada fase treatment ke3 dan ke-4, skor kemandirian subjek meningkat

Terlihat ada peningkatan skor yang signifikan antara fase baseline dan fase treatment. Pada fase baseline kemampuan subjek berada pada skor 8 , skor ini menunjukan kemandirian subjek masuk dalam kriteria rendah sedangkan pada fase treatment skor meningkat secara bertahap. Pada fase treatment ke-1 dan ke-2 skor kemandirian subjek masih masuk dalam kriteria sedang dan pada fase treatment ke3 dan ke-4, skor kemandirian subjek meningkat tinggi.

Terlihat ada peningkatan skor yang signifikan antara fase baseline dan fase treatment. Pada fase baseline kemampuan subjek berada pada skor 6, skor ini menunjukan kemandirian subjek masuk dalam kriteria rendah sedangkan pada fase treatment skor meningkat secara bertahap. Pada fase treatment ke-1 dan ke-2 dan ke-3 skor kemandirian subjek masih masuk dalam kriteria sedang dan pada fase treatment ke-4, skor kemandirian subjek meningkat tinggi.

\section{Kesimpulan :}

Berdasarkan atas hasil perhitungan skor aspek pada kemandirian subjek, diperoleh hasil bahwa aspek kemandirian yang proses peningkatannya paling tinggi adalah aspek mengurus diri.

\section{Hasil Pengolahan Data Penunjang}

\section{Hasil Observasi Selama Terapi}

Pada pertemuan pertama, kedua dan ketiga subjek masih beradaptasi, subjek hadir di tempat tanpa mendapatkan serangkain kegiatan program binadiri, subjek hanya hadir ke sekolah dan bermain dengan temantemannya. Pada pertemuan ke-empat subjek sudah mulai menerima kegiatan program binadiri namun subjek terlihat harus banyak dibantu dalam menyelesaikan tugas. Pertemuan kelima subjek mulai bisa menyelesaikan tugas dengan sedikit bantuan dan pada pertemuan ke-enam dan ke-tujuh subjek sudah mulai memperlihatkan perubahan selama mengikuti program binadiri hal tersebut terlihat dari kemampuan subjek dalam menyelesaikan tugas yang diberikan.

\section{Wawancara Pihak Terkait}

Melalui wawancara dengan pendidik dan orang yang mengasuh $\mathrm{S}$ diperoleh data tambahan mengenai anak bina sebagai berikut :

$\begin{array}{crcc}S & \text { adalah } & \text { anak dengan } & \text { kondisi } \\ \text { orang } & \text { tua } & \text { yang } & \text { kurang }\end{array}$
memperhatikannya karena sejak $S$ berusia kurang dari satu tahun kedua orang tuanya sudah bercerai sehingga $S$ diasuh oleh neneknya. Kemudian setelah $\mathrm{S}$ berusia 2 tahun $\mathrm{S}$ diasuh oleh paman dan tantenya karena paman dan tantenya ingin merawat seorang anak yang kebetulan paman dan tantenya belum dikaruniai seorang anak. Selama pengasuhan paman dan tantenya, $S$ sedikit lebih diperhatikan karena paman dan tantenya sangat menyayanginya dan sudah dianggap seperti anak kandung mereka. Pada awal paman dan tantenya membawa $S$ yakni pada usia dua tahun, tante $\mathrm{S}$ sudah mengetahui keaadaan fisik $S$ yang tidak normal yakni bagian kaki bagian kiri S ukurannya lebih kecil daripada kaki bagian kanan, $S$ pun baru bisa berjalan ketika sudah berusia 3 tahun. Tante $\mathrm{S}$ sering mengeluh dengan kondisi S karena prilaku-prilaku S tidak sama dengan anak seusia lainnya, tante $\mathrm{S}$ mengatakan walaupun sudah berusia 6 tahun tetapi prilaku S masih tetap saja kaya anak yang masih berusia 4 tahun, diantara prilaku tersebut, kalau $\mathrm{S}$ mau 
makan atau mau pergi ke WC untuk buang air kecil maupun BAB masih saja harus dibantu dan tidak mampu melakukannya secara sendiri. Dari hal itu kebetulan tetangga $S$ adalah seorang pendidik salah satu SLB setempat dan merujuknya untuk bersekolah disana. $\mathrm{S}$ dimasukan ke Slb ketika berusia 8 tahun atas kemauan paman dan tantenya, pada awalnya $\mathrm{S}$ tidak mau sekolah namun paman dan tantenya memaksanya dan akhirnya S mau untuk bersekolah. Setiap pergi ke sekolah $\mathrm{S}$ selalu dianter oleh tantenya. Respon pertama $\mathrm{S}$ masuk Slb terlihat riang dan gembira, karena disana $\mathrm{S}$ bisa bertemu dengan banyak teman dan bisa bermain sambil belajar dengan mereka.

\section{Auto Anamnesa}

\section{- Status Praesans}

Ketika selama pemberian program binadiri dan melakukan wawancara, $S$ selalu memakai seragam SD dengan kemeja warna putih berdasi merah, kebawahan celana pendek selutut warna merah dan sepatu hitam. Warna kulit $S$ hitam manis dan bermata sipit. Potongan rambut $S$ sedikit agak botak. Selama melakukan wawancara, $S$ tidak banyak bicara panjang hanya memberikan jawaban yang singkat.

- Anamnesa

$\mathrm{S}$ adalah seorang siswa Sekolah Luar Biasa kelas 1, usianya 8 tahun. Ia anak kedua dari dua bersaudara. Adapun urutan dalam keluarganya yaitu sebagai berikut :

\begin{tabular}{llll}
\hline No & $\begin{array}{l}\text { Jenis } \\
\text { kelamin }\end{array}$ & Usia & $\begin{array}{l}\text { Pendidikan } \\
\text { terakhir }\end{array}$ \\
\hline 1 & $\begin{array}{l}\text { Laki- } \\
\text { laki }\end{array}$ & $\begin{array}{l}17 \\
\text { tahun }\end{array}$ & SMA \\
2 & $\begin{array}{l}\text { Laki- } \\
\text { laki }\end{array}$ & $\begin{array}{l}8 \\
\text { tahun }\end{array}$ & $\begin{array}{l}\text { Pelajar } \\
\text { kelas I SLB }\end{array}$ \\
\hline
\end{tabular}

S dilahirkan dalam usia kandungan Sembilan bulan. S dilahirkan secara tidak normal yakni harus operasi caesar dengan kondisi fisik yang tidak normal, yakni bagian kaki S sebelah kiri ukurannya lebih kecil dari pada bagian kanan. S lahir dengan berat badan $3.5 \mathrm{~kg}$ dan panjang sekitar $50 \mathrm{~cm}$. Selama masa kehamilan pada usia kandungan Sembilan bulan, ibu S sempat jatuh sehingga mengharuskan ibu S untuk di rawat di rumah sakit.

Perkembangan motorik $\mathrm{S}$ berkembang agak lambat dari kebanyakan anak yang lainnya, S mulai bisa berjalan sekitar usia 3 tahun, karena menurut teori pada usia 18 hingga 24 bulan, anak-anak yang baru berjalan dapat berjalan cepat atau berlari dengan susahpayah untuk suatu jarak yang pendek, menyeimbangkan kaki mereka dalam posisi berjongkok sambil bermain dengan benda-benda di atas lantai, berjalan mundur tanpa kehilangan keseimbangan, berdiri dan menendang bola tanpa jatuh, berdiri dan melemparkan bola, dan melompat di tempat (Schirmer,1974).

Kedua orang tuanya sudah bercerai dan sudah lama meninggalkan $\mathrm{S}$, sehingga $\mathrm{S}$ sekarang diasuh oleh paman dan tantenya. S lebih banyak menghabiskan waktu bermain di rumah bersama paman dan tantenya.

Di sekolah $\mathrm{S}$ bermain dengan semua teman, baik laki-laki maupun perempuan akan tetapi lebih dekat dengan anak laki-laki. Ketika berada di rumah, $\mathrm{S}$ sering belajar dengan tantenya sedangkan paman $\mathrm{S}$ kurang begitu membantunya dalam belajar.

S lebih dekat dengan tantenya daripada dengan pamannya, dalam hal pendidikan tantenya yang lebih banyak mengarahkan dan tantenya juga selalu menjalin komunikasi dengan guru-guru untuk menanyakan perkembangan S selama di sekolah. 
Dalam melakukan aktivitas seharihari, S masih belum bisa melakukan dengan sendiri dan sering dibantu oleh tantenya, dari mulai makan, mandi, sampai memakai baju sebelum berangkat ke sekolah. Setiap pulang dari sekolah tante $\mathrm{S}$ sering kali menanyakan kepada $\mathrm{S}$ mengenai materi yang telah didapatkan di sekolah dan juga sering membantu $S$ ketika mengalami kesulitan dalam belajar.

\section{Hasil Pengujian Hipotesis Tandingan (Rival Hypotesis)}

Kecepatan atau keterlambatan peningkatan kemandirian pada anak tunagrahita dalam penelitian ini dipengaruhi juga oleh factor-faktor dibawah ini :

1. History, hal ini tidak dapat dikontrol karena dapat terjadi diantara pengukuran pertama dan kedua, sehingga kejadian yang terjadi dapat mempengaruhi pengukuran kedua, yakni berkaitan dengan factor kerjasama anak bina dengan pendidik

2. Maturation, hal ini tidak dapat dikontrol karena dapat muncul atau terjadi pada responden selama waktu pengukuran, hal ini berkaitan dengan faktor kelelahan dan kejenuhan.

\section{PEMBAHASAN}

Berdasarkan atas hasil perhitungan kemandirian yang telah dilakukan pada subjek, diperoleh hasil terjadinya perubahan atau peningkatan skor kemandirian yang signifikan pada anak tunagrahita antara fase baseline dan fase treatment. Hal ini menunjukan bahwa hasil penelitian terdapat pengaruh program binadiri terhadap kemandirian anak tunagrahita Slb Abc Argasari Yayasan Lestari Tasikmalaya.

Terdapatnya pengaruh program binadiri terhadap kemandirian anak tunagrahita, membuktikan bahwa program binadiri yang dilaksanakan oleh anak tunagrahita di Slb Abc Argasari Yayasan Lestari Tasikmalaya selama kurang lebih 3 bulan memberikan dampak meningkatnya kemandirian pada anak tunagrahita selama program binadiri dilaksanakan.

Program Bina Diri merupakan program yang khusus diberikan kepada anak tunagrahita yaitu mencakup suatu usaha yang dilakukan SLB untuk mengembangkan kemampuan diri anak tunagrahita yaitu berupa latihan-latihan yang disesuaikan dengan keadaan anak tersebut. Program Bina Diri memiliki peran sentral dalam mengantarkan peserta didik dalam melakukan bina diri untuk dirinya sendiri, seperti merawat dan mengurus diri, menjaga keselamatan diri, komunikasi serta adaptasi lingkungan sesuai dengan kemampuannya. Pembelajaran bina diri diarahkan untuk mengaktualisasikan dan mengembangkan kemampuan peserta didik dalam melakukan bina diri untuk kebutuhan dirinya sendiri sehingga tidak sepenuhnya membebani orang lain.

Dalam penerapan program binadiri, terdapat proses yang dilalui sehingga dari proses tersebut menyentuh beberapa aspek psikologis dari anak tunagrahita. Proses awal yang dilakukan adalah pemberian materi yang berkaitan dengan materi kemandirian, disini anak tunagrahita akan diberikan materi atau informasi seperti layaknya proses belajar mengajar.

Proses pemberian materi merupakan langkah awal proses belajar, dimana pada tahap ini anak tungrahita mulai menerima informasi sebagai stimulus dan melakukan respons terhadapnya, sehingga menimbulkan pemahaman dan perilaku baru. Pada tahap ini terjadi pula asimilasi antara pemahaman dan perilaku baru dalam keseluruhan perilakunya. Seringkali dalam pemberian materi, anak tunagrahita disuruh untuk mencatat materi yang telah diberikan agar anak tunagrahita mampu mengingat materi yang telah diberikan dan juga terkadang pendidik memberikan 
beberapa pertanyaan sederhana kepada anak tunagrahita sebagai bahan evaluasi.

Hal ini sesuai dengan apa yang dikatakan Wittig (1981) dalam bukunya Psychology of Learning, setiap proses belajar selalu berlangsung dalam tiga tahapan :

a. Acquisition (tahap perolehan / penerimanaan informasi).

b. Storage (tahap penyimpanan informasi).

c. Retrieval (tahap mendapatkan kembali informasi.

Proses selanjutnya adalah anak tunagrahita dilatih secara khusus melakukan tingkah laku yang berkaitan dengan binadiri, dengan metode sebagai berikut :

a. Prompting, yaitu menyuruh anak untuk melakukan tingkah laku yang dimaksud dengan kata-kata, dengan mimik, dengan bantuan tangan.

b. Modeling, menyuruh anak untuk melakukan sesuatu dengan mencontoh tingkah laku yang diperagakan guru.

c. Role playing, menyuruh anak untuk melakukan sesuatu sesuai dengan peran yang ditugaskannya.

d. Learning center, anak dapat melakukan sesuatu sesuai dengan tugas-tugasnya yang ada pada pusat/sudut belajar.

Menurut Barlow (1985), sebagai besar dari yang dipelajari manusia terjadi melalui peniruan (imitation) dan penyajian contoh perilaku (modeling). Dalam hal ini, anak tunagrahita belajar mengubah perilakunya sendiri melalui penyaksian cara orang atau sekelompok orang mereaksi atau merespons sebuah stimulus tertentu. Anak tunagrahita ini juga dapat mempelajari respons-respons baru dengan cara pengamatan terhadap perilaku contoh dari orang lain, misalnya guru atau orang tuanya.

Keberhasilan penerapan pembelajaran bina diri pada anak tunagrahita ada beberapa faktor yang berpengaruh, baik pengaruh dari dalam individu maupun pengaruh dari luar individu.. Pengaruh dari dalam individu yang dapat dikemukan dari hasil pengamatan penelitian adalah motivasi yang tinggi dan minat dari anak. Ada beberapa kemungkinan munculnya motivasi dari anak yaitu pembelajaran bina diri yang mengaktifkan anak sehingga lebih menarik tidak mudah bosan. Karena menurut Menurut Abdul Gafur (2003: 32) bahwa salah satu faktor yang mempengaruhi kemandirian adalah factor dari dalam individu yakni kondisi psikis, yaitu kondisi kejiawaan dari individu. Kondisi kejiwaan yang mempengaruhi kemandirian adalah intelegensi, motivasi dan sikap.

Adapun faktor yang mendukung dari luar anak sehingga kemandirian anak meningkat adalah lingkungan kelas dan guru sebagai faktor utama. Penerapan pembelajaran bina diri bila hanya disampaikan secara monoton dan konvensional maka akan berpengaruh pada minat belajar siswa. Namun bila dalam pembelajaran itu di kombinasikan dengan lingkungan maka hasilnya akan berpengaruh pada diri anak. Penciptaan lingkungan kelas sangat perlu karena hal ini mengurangi kejenuhan anak dalam belajar. Dari pelaksanaan penelitian yang telah dilakukan bahwa dalam setiap pertemuan harus mengubah posisi belajar anak memang memberikan dampak yang positif pada anak. Karena berdasarkan adaptasi dari Kirk \& Gallagher, 1986:125) namun dibalik keterbatasan yang dimiliki anak tunagrahita, mereka menunjukan ketekunan dan rasa empati yang baik asalkan mereka mendapatkan layanan atau perlakuan dari lingkungan yang kondusif.

Pengaruh keberhasilan penerapan pembelajaran bina diri yang sangat berperan dalam pembalajaran dikelas adalah guru. Inilah yang akan memberikan kunci utama dalam keberhasilan pembelajaran. Guru harus memiliki kemampuan kreatifitas yang cukup, motivasi yang tinggi. Karena dalam mengelola anak-anak berkebutuhan khusus tidak hanya mengandalkan kasih sayang pada anak. Seni mengolah kelas 
merupakan kreativitas yang harus dimiliki oleh guru, karena dengan mengola kelas akan dapat menimbulkan suasana yang selalu berubah sehingga semangat belajar anak meningkat.

Kerjasama antara orang tua dengan pendidik juga merupakan salah satu faktor yang sangat penting dalam meningkatkan kemandirian anak tunagrahita untuk menguasai materi yang diberikan selama program binadiri. Pengulangan anak untuk menguasai materi diperlukan pengulangan dan generalisasi dalam setting yang lebih luas dan keluarga dapat melakukan aktivitas itu di rumah dengan waktu yang lebih lama. Hal ini akan berpengaruh kepada anak tunagrahita dalam menyerap informasi untuk menguasai materi karena menurut Santrock (2009:255) "reterdasi mental adalah kondisi yang dimulai sebelum usia 18 tahun yang melibatkan intelegensi rendah (biasanya dibawah 70 dalam tes intelegensi tradisional yang dilakukan sendiri) dan kesulitan dalam menyesuaikan diri dengan kehidupan sehari-hari". Tentunya ketika anak mengalami kesulitan dalam menyesuaikan diri dengan kehidupan sehari-hari akan sulit juga untuk anak dalam memahami dan menguasai materi yang diberikan selama program berjalan. Dengan kesulitan yang dialami oleh anak tunagrahita, faktor kerjasama antara orang tua dengan pendidik dalam usaha membantu anak tunagrahita dalam rangka meningkatkan kemandirian sangatlah penting. Karena berdasarkan adaptasi dari James D. Page (Suhaeri, HN: 1979) bahwa anak tunagrahita tidak dapat mengurus, memelihara dan memimpin diri, sehingga mereka harus dibantu terus karena mereka mudah terperosok kedalam tingkah laku yang kurang baik.

Berdasarkan hasil observasi dan wawancara yang telah dilakukan, tante $\mathrm{S}$ sering kali menjalin komunikasi dengan pendidik untuk memantau perkembangan $\mathrm{S}$ selama berada di sekolah. Selain di sekolah, di rumahnya pun $\mathrm{S}$ sering diajarkan latihan atau tugas-tugas oleh tantenya yang berkaitan dengan kemandirian, seperti cara memakai baju, memakai sepatu, mandi dll. Tidak hanya itu saja yang dilakukan oleh tante $\mathrm{S}$, bahkan ketika $\mathrm{S}$ mengalami kesulitan dalam menerima materi program binadiri disekolah, tante $\mathrm{S}$ suka membantunya.

Faktor lainnya yang mempengaruhi peningkatan kemandirian anak tunagrahita adalah frekuensi kehadiran dalam program binadiri. Faktor ini terkait dengan waktu dan kesempatan anak tunagrahita untuk mendapatkan materi, juga terkait dengan kontinunitas program binadiri untuk mengkondisikan anak tunagrahita supaya terbiasa dalam suasana belajar.

Kategori anak tunagrahita juga sangat mempengaruhi dalam peningkatan kemandirian anak tunagrahita. Berdasarkan kalsifikasi yang digunakan di indonesia saat ini sesuai dengan PP 72 Tahun 1991 adalah sebagai berikut :

1) Tunagrahita ringan IQ-nya 50-70

2) Tunagrahita sedang IQ-nya 30-50

3) Tunagrahita berat dan sangat berat IQnya kurang dari 30

Anak dengan kategori ringan dalam berbicaranya banyak yang lancar, tetapi perbendaharan katanya minim, Mereka mengalami kesulitan dalam berpikir abstrak, tetapi mereka masih mampu mengikuti pelajaran yang bersifat akademik atau tool subject, baik di sekolah biasa maupun di sekolah luar biasa (SLB). Umur kecerdasannya apabila sudah dewasa sama dengan anak normal yang berusia 12 tahun. Dengan demikian anak tunagrahita yang termasuk kategori ringan dilihat dari IQ dan karakteristiknya akan sedikit lebih cepat dalam meyerap informasi dan penanganan yang dilakukan di sekolah luar biasa dibanding dengan anak yang termasuk dalam kategori sedang dan berat.

Namun terlepas dari faktor-faktor tersebut, bahwa hasil penelitian menunjukan terjadinya peningkatan kemandirian anak tunagrahita setelah melakukan program binadiri. Rosulullah 
SAW telah memberikan contoh begaimana seharusnya mempersiapkan seorang agar mendiri dan memiliki kemampuan-kemampuan untuk menjalani kehidupan sebagai seorang hamba, salah satunya yang disebutkan oleh Abdurahman (2002), yakni memberi semangat untuk mandiri dan bekerja keras, Rosulullah saw sangat memperhatikan pengembangan bakat anak di bidang social dan ekonomi dalam rangka membangun rasa percaya diri dan kemandirian. Sehingga anak dapat berinteraksi dengan berbagai unsur di dalam masyarakat dan menjalani hidupnya dengan penuh kesungguhan dan tidak ada unsure kemanjaan di dalam dirinya. Begitu dengan dukungan yang diberikan oleh tante $\mathrm{S}$ selama ini, di sekolah maupun di rumah, tante $S$ selalu ada disampingnnya dan berusaha untuk memberi semangat untuk mandiri dan mau bekerja keras.

\section{SIMPULAN}

Berdasarkan hasil dan pembahasan penelitian yang telah dilakukan dapat disimpulkan sebagai berikut:

1. Pemberian program binadiri berpengaruh terhadap kemandirian pada anak tunagrahita (kategori ringan) Slb Abc Argasari Yayasan Lestari Tasikmalaya. Hal ini ditunjukan dengan adanya peningkatan skor kemandirian pada fase setelah treatment.

2. Aspek kemandirian yang paling meningkat tinggi pada anak tunagrahita (kategori ringan) adalah aspek mengurus diri.

3. Jika terdapat aspek kemandirian yang kurang meningkat, kemungkinan dipengaruhi oleh kurangnya kerjasama antara anak tunagrahita dengan dengan pendidik, kurangnya motivasi baik dari dalam maupun dari luar, serta adanya kelelahan dan kejenuhan selama mengikuti program binadiri.

\section{SARAN}

Berdasarkan hasil penelitian yang diperoleh ada beberapa saran yang peneliti coba sampaikan kepada pihak-pihak yang terkait, yaitu:

Pihak pendidik Slb :

1. Adanya dukungan orang dari para orang tua selama dalam proses program bina diri, agar ketika anak berada di lingkungan anak merasa nyaman berada dalam lingkungan keluarganya sehingga anak mempunyai motivasi untuk terus mempertahankan kemampuan kemandiriannya.

2. Adanya kerjasama yang lebih efektif lagi antara anak tunagrahita dengan pendidik selama dalam proses program bina diri agar anak terhindar dari rasa jenuh.

\section{DAFTAR PUSTAKA}

Astati. 2010. Binadiri untuk anak tunagrahit. Bandung: CV.Catur Karya Mandiri

Casmini, Mimin.2007. Pengajaran Bina Diri Dan Bina Gerak (Bdbg).

Davison, G. Neale, J \& Kring, A. 2006. Psikologi Abnormal Edisi Ke-9. Jakarta: RajaGrasindo Persada

Delphie, Bandi. 2006. Pembelajaran Anak Berkebutuhan Khusus.Bandung: PT.Refika Aditama

Departemen pendidikan nasional. 2009. Bahan Ajar Pembelajaran Bina Diri untuk peserta didik tunagrahita tingkat SDLB (Pedoman Guru). Bandung : Pemerintah Provinsi Jawa Barat Bidang Pendidikan Luar Biasa Kegiatan Pengembangan Kurikulum Pembelajaran Dan System Penilaian PK-PLK

Departemen Pendidikan Nasional. 2003. Program Khusus Bina Diri Bisakah Anakku Mandiri. Jakarta: Direktorat Pendidikan Dasar dan Menengah \&Direktorat Pendidikan Luar Biasa. 
Feist, Jess, Gregory J.Feist. 2008. Theories of Personality Edisi keenam. Yogyakarta : Pustaka Belajar

Gerungan. 2004. Psikologi Sosial. Bandung : PT Refika Aditama

Hadi, Sutrisno.1995. Metodelogi Research. Yogyaakarta : Andi Offset

Harini, Sri. Ririen Kusumawati. 2007. Metode Statistika. Jakarta: Prestasi Pustakaraya

Hurlock. 1998. Perkembangan anak. Jakarta: Erlangga.

Mangunson, Frida 2011. Psikologi dan pendidikan anak berkebutuhan khusus jilid kedua. Jakarta : LPSP3

Muhammad541d, 2009. http://muhammad541d.wordpress.co m/2009/03/10/fitrah-manusial (di unduh tanggal 14 mei 2011)

Nurce, $C$.

2011

http://dyanmalida.blogspot.com/201 1/05/hubungan-peran-orang-tuadengan-tingkat.html (di unduh tanggal 11 mei 2011)

Papalia Diane E., et. al. 2008. Human Development (Psikologi Perkembangan).

Alih Bahasa: A.K. Anwar. Jakarta: Prenada Media Group

Santrock, John W. 2002. Life Span Development: Perkembangan Sepanjang Masa

Hidup. Edisi 5, Jilid 1. Jakarta: Erlangga
Senjaya,S.2010.http://sutisna.com/artikel/a rtikelkependidikan/pengertiankeman dirian/ (di unduh tanggal 7 mei 2011)

Sudjana, 1995, Desain Dan Analisis Eksperimen Edisi IV.Bandung : Tarsito

Sudjana. 1992. Metoda Statistika. Bandung : Tarsito

Sunanto, Juang, Koji Takeuchi (2005). Pengantar Penelitian Dengan Subyek Tunggal. Tsukuba : CRICED University of Tsukuba,

Syah, Muhibin. 2008. Psikologi Pendidikan dengan Pendekatan Baru. Bandung : PT Remaja Rosdakarya

Steinberg, Laurence. (2002). Adolescene : McGraw-Hill Inc.

Zainun Mu'tadin. (2002). KIemandirian sebagai Kebutuhan Psikologis pada Remaja. National Computational Information

CoordinatingCommittee,http://www. uncg.edu : 80/ericcas 2/assessment/html.

Zimmer-Gembeck, M.J. (2001). Autonomy in adolescence. In J. V. Lerner \& R. M. Lerner (Eds.), Adolescence in America: An Encyclopedia. Denver, CO: ABC CLIO. 